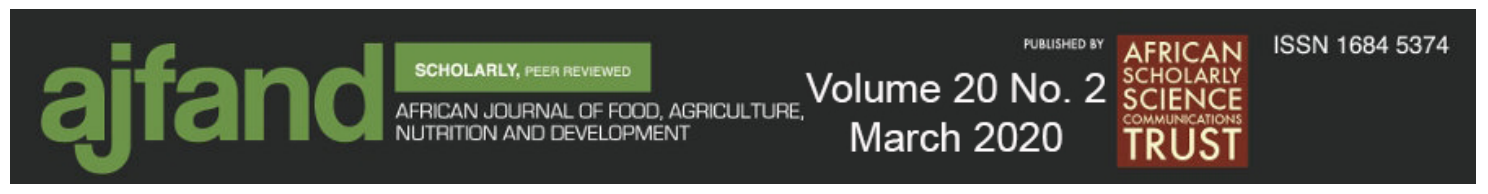

Afr. J. Food Agric. Nutr. Dev. 2020; 20(2): 15637-15659

DOI: 10.18697/ajfand.90.19285

\title{
RECOMMENDED MODIFICATION OF PORRIDGE AND MIXTURE TO IMPROVE NUTRIENT INTAKE IN THE RURAL AREA OF NORTHERN RWANDA
}

\author{
Tanno $Y^{1}$, Sudo $N^{2 *}$, Kano $M^{3}$, Mukuralinda $A^{4}$, \\ Mukantwali $C^{5}$, Mujawamariya $P^{4}$, Ruganzu $V^{5}$ and M Iiyama ${ }^{6}$
}

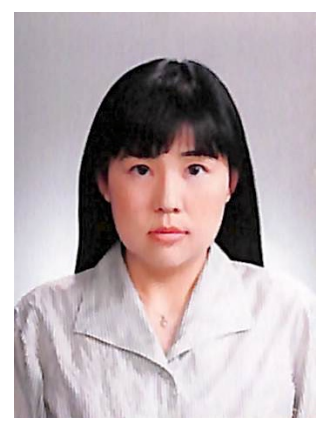

Noriko Sudo

*Corresponding author email: sudo.noriko@ocha.ac.jp

${ }^{1}$ Department of Nutrition and Food Science, Faculty of Human Life and Environmental Science, Ochanomizu University, Tokyo, Japan

${ }^{2}$ Natural Science Division, Faculty of Core Research, Ochanomizu University, Tokyo, Japan

${ }^{3}$ Graduate School of Humanities and Sciences, Ochanomizu University, Tokyo, Japan ${ }^{4}$ World Agroforestry (ICRAF), Butare, Rwanda

${ }^{5}$ Rwanda Agriculture and Animal Resources Development Board (RAB), Butare, Rwanda

${ }^{6}$ Japan International Research Center for Agricultural Sciences, Ibaraki, Japan 


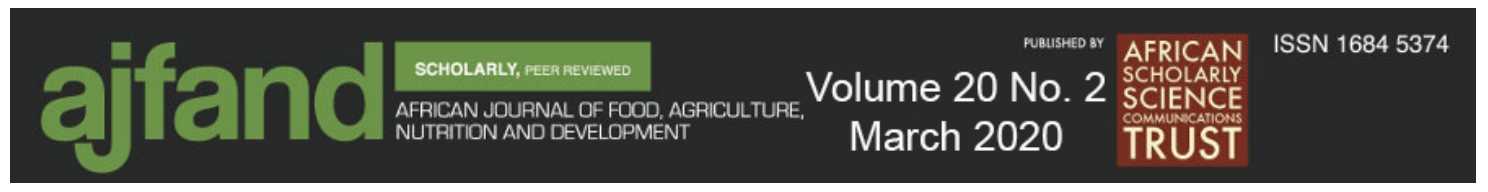

\section{ABSTRACT}

In Rwanda, nutritional problems are increasingly drawing attention, and the National Nutrition Policy focuses on the solutions to reduce the prevalence of malnutrition and to improve household food intake. Since rural Rwandans typically have meals at home and household food intake is known to be affected by their socioeconomic status (SES), care should be taken to ensure that homemade meals are healthy. This study aimed to assess the current nutrient content of porridge and mixture so as to recommend modifications to be made to improve nutrient intake within rural households in Rwanda. A crosssectional study was conducted; anthropometric measurements and one-day weighed food records (WFRs) were collected from 30 participants in four households with different SES in the Musanze district in the Northern Province of Rwanda. The first objective of this study was to compare nutritional status and food intake among households with different SES. The study results indicated that SES did not solely explain the nutritional status of the household members, and co-existence of over-nutrition and undernutrition was observed within the better-off household. Although meal frequency per day and the number of dishes and ingredients were positively related to household SES, rural Rwandans consumed monotonous diets characterized by porridge for breakfast and mixture (a dish boiled some foods together) for lunch and dinner as a whole. These two familiar dishes, porridge and mixture, greatly affected their energy and nutrient intakes. The second objective was to compare energy and nutrient contents in the same dishes with different ingredients and cooking methods. Porridges were made by dissolving mixed flour (maize and sorghum flours) in hot water. The porridge did not contain vitamin A. The energy, protein, and iron contents of the porridge were affected by flour concentration. Thick porridge whose flour concentration is $13 \%$ is recommended. Beans and potatoes were popular ingredients of mixture. Beans were major sources of energy, protein, and iron intakes. Contrary to general assumption, roots and tubers were also the major sources of protein and iron intakes among the participants. To cook mixture that is well boiled and contains beans and potatoes is a feasible way to increase energy and nutrient intakes regardless of household SES. In order to provide good vitamin A intake, addition of yellow plantain, palm oil, and/or tomato is recommended. This study presents locally and economically feasible recommendations to make popular dishes more nutritious for rural Rwandans.

Key words: Household food intake, socioeconomic status, ingredients, cooking methods, rural Rwanda 


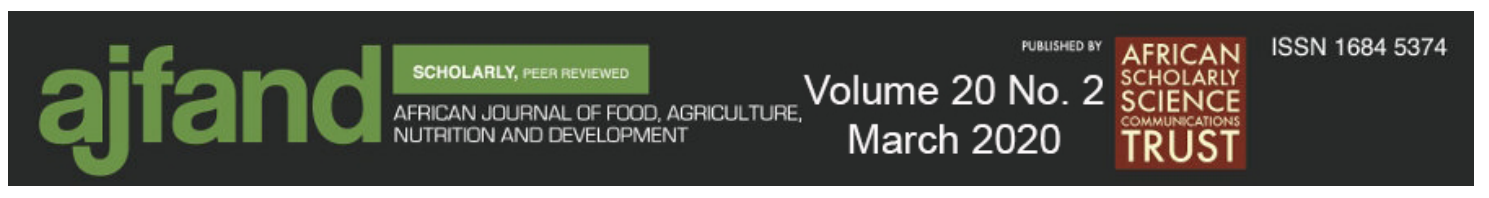

\section{INTRODUCTION}

In Rwanda, nutritional problems are increasingly drawing attention. The first National Nutrition Policy was adopted in 2007, aiming to detect and treat malnutrition [1]. Malnutrition is not only a health problem but also an economic problem [2]. Reduction of malnutrition is necessary for achieving sustainable development goals and it is considered not only an investment for but also an outcome of sustainable development [2]. The new National Nutrition Policy adopted in 2013 focuses on the solutions to reduce the prevalence of malnutrition and to improve household food intake [1].

Food intake is a main contributor to nutritional status. Previous studies revealed monotonous dietary patterns and poor dietary quality in rural Rwanda [3,4]. Since rural Rwandans typically have meals at home, care should be taken to ensure that homemade meals are healthy [5]. It has been demonstrated that household food insecurity and low dietary diversity are associated with household income [6,7]. Since nutritious foods such as animal-based foods and fortified foods are expensive, recommendations to increase the intake of expensive nutritious foods that are not currently used are neither feasible nor effective [1]. Moreover, previous studies showed that high awareness of nutrition among rural households did not directly affect the consumption of nutrient-rich foods $[8,9]$. For these reasons, it is important to teach households how they could modify their current food intake with locally and economically available foods.

In order to investigate how their diets could be improved, a cross-sectional study was conducted. Weighed food records (WFRs) were collected from four households with different socioeconomic status (SES). The first objective of this study was to compare nutritional status and food intake among better-off, medium, and poor households. It was hypothesized that this information would help to determine how economic constraints affect food availability and the resulting nutritional status.

The second objective was to compare energy and nutrient contents in the same dishes with different ingredients and cooking methods. This could make it possible to cook the same familiar dishes while improving the nutritional value by changing or adding commonly used ingredients and modifying cooking methods. 


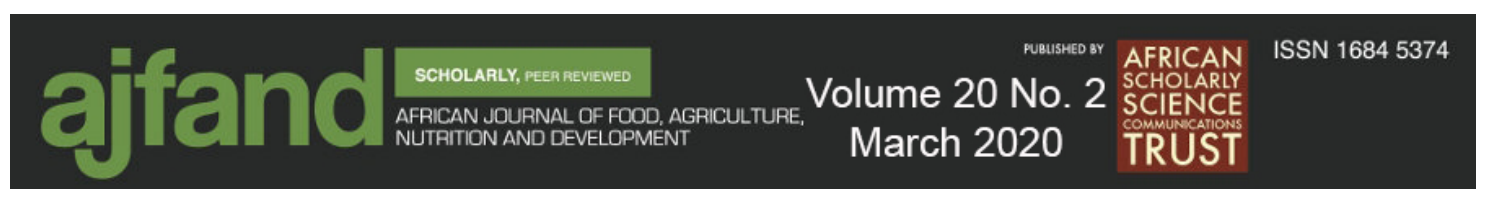

\section{METHODS}

\section{Study site}

The Republic of Rwanda is a landlocked country located in east-central Africa. It shares its borders with Uganda in the north, the Democratic Republic of the Congo in the west, Burundi in the south, and Tanzania in the east. There are many hills and mountains, and its population density is the highest in Africa. Although Rwanda has experienced economic growth in the past two decades, poverty is still a challenging problem. Approximately $39 \%$ of Rwandans live below the national poverty line, and $16 \%$ of them live in extreme poverty [10].

This study was conducted in the Musanze district, a rural area in the Northern Province. It has a tropical climate, and the average temperature is $20^{\circ} \mathrm{C} \mathrm{[11].} \mathrm{This} \mathrm{study} \mathrm{site} \mathrm{has}$ two seasons: the rain seasons are September to December and March to May, while the dry seasons are June to August and January to February [11]. Approximately three million people live in the area of $530 \mathrm{~km}^{2}$ [12]. Musanze has the Volcanoes National Park, which is famous for gorillas.

Maize and Irish potatoes are the two most important food and commercial crops. These crops are usually grown rotationally on the same plots. While many households also grow climbing beans and bananas (cooking or plantain varieties, usually several banana trees on a single home compound), they are predominantly only for home consumption. According to our additional interview survey on agriculture, a few households answered they grew amaranth in their home garden and sorghum in one of the plots rotating with climbing beans. Both amaranth and sorghum are rich in protein and iron. Given rather the lack of diversity in nutrient-rich food grown agriculturally, farmers are encouraged to adopt iron-rich beans (already introduced to a few farmers in the village and surrounding areas) and also to diversify into growing greater varieties of vegetables.

\section{Participants}

Four households in Musanze were selected by convenience sampling method [13]. While measuring the meals of one household, we also called on other households to ascertain the next day's WFR. Some of the authors (M Iiyama and A Mukuralinda) assisted by a local translator-cum-assistant conducted additional interviews on agriculture for 16 nearby households in the same period. Therefore, the households had to be conveniently located to facilitate the research schedule. 


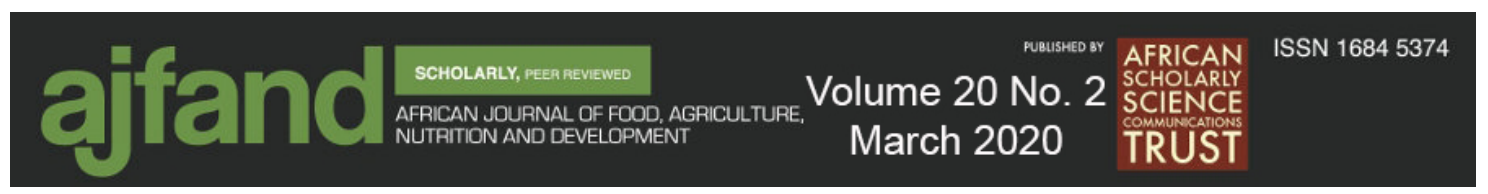

The following two criteria were used for selection of households: (1) large families in order to collect as much data as possible in the three-day period of field survey, and (2) households with specific SES (one better-off, two medium, and one poor household). Socioeconomic status (SES) was determined by subjective overall evaluation by an official village leader who knew all the households in the village. However, the descriptive statistics of the livelihood status of the 16 neighbouring households indicated that the four households selected for WFR were distinctive in terms of socio-economic ranking. Although there were other households that met the above two criteria, the village leader selected these four families as representatives of each SES while considering logistical convenience and our research purpose.

\section{Data collection}

Weighed food record (WFR) and anthropometric measurements (height and weight) were carried out from 13-15 August in 2018.

\section{Weighed food record (WFR)}

One-day WFR was collected from 30 participants in four households. A team comprising a Japanese researcher (experienced registered dietitian nutritionist) and a Rwandan researcher (senior research fellow) surveyed one household each day for three days. The Rwandan researcher was responsible for the study of one household only on the second day. These investigators stayed at each household from early morning to evening in order to observe and weigh the foods consumed over that day. First, investigators weighed all ingredients before cooking. After cooking, the total weight of the cooked food was measured, and the percentages of each raw ingredient used in it were calculated.

\section{Anthropometric measurement}

Using measured height and weight, body mass index (BMI) was calculated for all members of the household. The BMI for adults (aged 20 years and over); BMI-for-age z-score for 5-19 year-olds; and height-for-age and weight-for-height z-scores for children 1-4 year-old were used as indicators of malnutrition $[14,15,16]$. When adults had BMI scores below 18.5, 5-19 year-olds had z-scores of BMI-for-age below -2, and 1-4 year-olds had height-for-age $\mathrm{z}$-scores below -2 , they were assessed as undernourished. When adults' BMI was over 25.0, 5-19 year-olds' BMI-for-age z-score was over +1 , and 1-4 year-olds' weight-for-height $\mathrm{z}$-score was over +2 , they were 


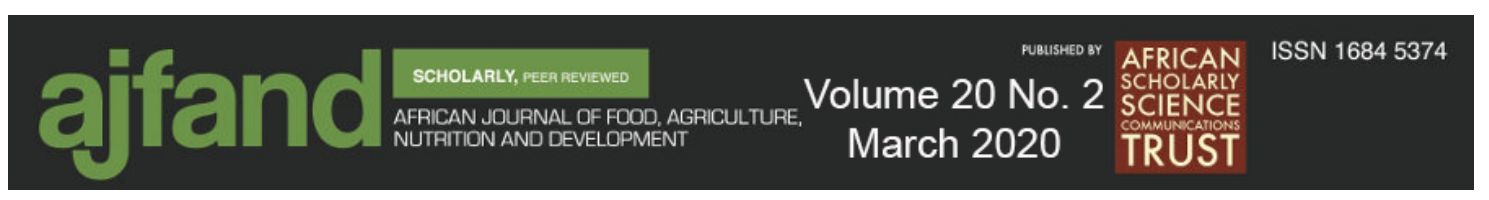

assessed as over-nourished $[14,15,16]$. The z-score for BMI-for-age was calculated by using the WHO method [16].

\section{Nutritional assessment of widely consumed dishes}

For the second purpose of this study, researchers focused on dishes that were commonly cooked in most families, aiming to propose achievable modifications for them. First, the dishes that were frequently observed, at least twice overall in the four households for the three-day survey period, were chosen. Next, energy and three nutrient contents of protein, vitamin $\mathrm{A}$, and iron in the dishes were calculated per $100 \mathrm{~g}$. These three nutrients were selected because their deficiencies are prevalent in Rwanda [1]. To calculate energy and nutrient contents, the food composition tables of Uganda [17], a neighboring country to Rwanda, were used because those for Rwanda were not available. For gourd (a green vegetable grown in home gardens), the values of "green-colored chayote" in Japanese food composition tables were used [18] because there were no data for gourd in the food composition tables of Uganda.

\section{Ethical consideration}

After the explanation of the study in the local language to the participants by Rwandan researchers, written informed consent was obtained from a representative of each household before the survey. This study was approved by the Institutional Review Board of Ochanomizu University (approval numbers 2018-65). The study was also approved by Rwanda Agriculture and Animal Resources Development Board (RAB) and World Agroforestry (ICRAF).

\section{RESULTS AND DISCUSSION Nutritional status by SES}

Although a significant positive relationship between wealth and household food security is reported [9], there were no malnourished people in the households with lowest SES (households IV) in this study (Table 1). On the contrary, there was an undernourished female (foster daughter) in the better-off household. Unequal intra-household food allocation is reported in developing countries; for example, more food is served to boys than girls, to first born than later born, and to biological children than foster children [19].

In the better-off family, there were both undernourished (the foster daughter) and overnourished women (the mother and the eldest daughter) within the same household. The 


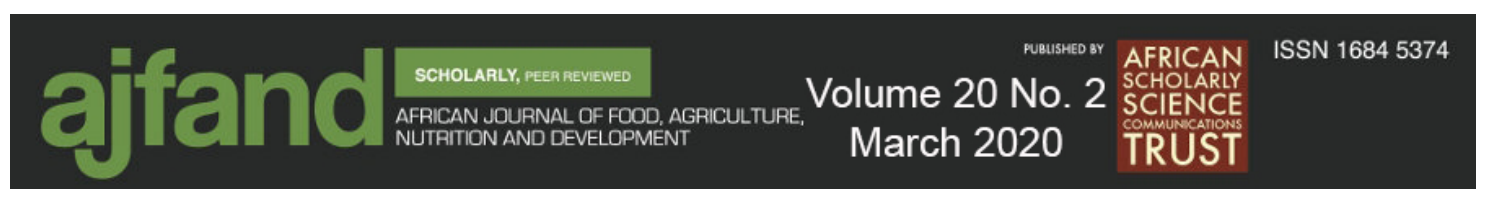

co-existence of undernutrition and over-nutrition is known as "the double burden of malnutrition" [20]. In rural Rwanda, undernutrition is still the problem, but the prevalence of thin people has been decreasing [12]. Conversely, the prevalence of overweight individuals has been increasing [12]. The Rwanda Demographic and Health Survey $2014-15$ reported that $4.5 \%$ of women are thin, and $20.7 \%$ are overweight in the Northern Province [12]. Even in the small sample size of 30 people, a similar prevalence was observed in this study. The double burden of malnutrition was also observed in this small community.

\section{Differences in food intake by SES}

Table 2 shows what participants ate over one-day. Skipping meals was observed in the households with lower SES (households III and IV). Household IV with the lowest SES skipped both breakfast and lunch. Moreover, the number of consumed food items was also related to SES, that is, the wealthier the household, the more varied the food items consumed. The better-off household had more varied foods than the poor household. Previous studies also reported that low income is associated with low dietary diversity $[7,9]$.

\section{Poor dietary diversity}

Micronutrient deficiencies are related to poor dietary diversity [21]. The only animal food observed in this study was beef stock consumed by the better-off households (Table 2 ). Villagers in developing countries consume only small amounts of meat products which provide protein with high amino acid scores and micronutrients with high bioavailability, such as heme iron and retinol $[22,23]$.

Overall, a limited variety of dishes has been observed in rural parts of developing countries [23-25]. Previous studies also mentioned that rural Rwandan diets were characterized by poor dietary diversity $[4,26]$. Table 2 shows that in many eating occasions, households cooked only one dish. Moreover, it has been reported that the same dish was often served for lunch and dinner in Rwanda [3]. Therefore, intakes of energy and nutrients were greatly affected by the contents of the dish.

In order to resolve micronutrient deficiencies, supplementation and food fortification have been implemented by the government and several organizations [1]. Although biofortified foods have been produced and promoted, they were not commonly used by 


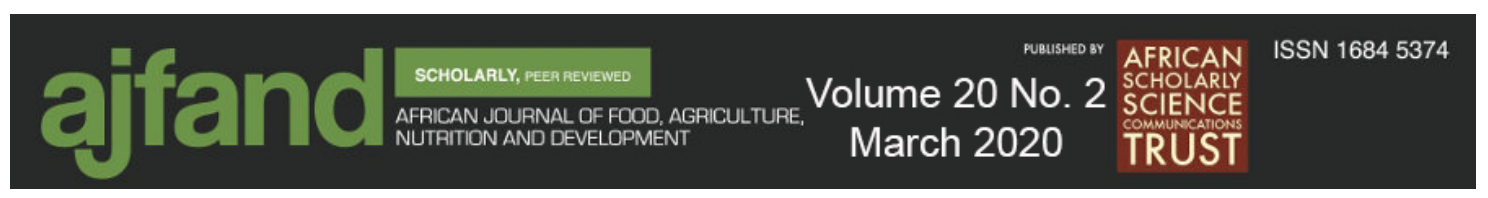

rural Rwandans because of the limited accessibility and high cost [1,27]. Therefore, dietary modification using available food items should be considered as an achievable way to improve micronutrient status.

\section{Calculation of energy and nutrient contents in porridge and mixture}

Energy and nutrient contents in porridge and mixture were evaluated since they were consumed at least twice or more (Table 2) and hence, they could be regarded as widely consumed dishes whose energy and nutrient contents had a great impact on daily energy and nutrient intakes.

\section{Porridge}

Two households (I and II) at breakfast ate porridge (Table 2). Porridge is a typical breakfast menu item in African countries, including rural Rwanda [28]. Table 3 shows energy and three nutrient contents in $100 \mathrm{~g}$ of two different porridges cooked by the two families. Nutrient contents in $100 \mathrm{~g}$ of porridge are shown because portion size of each person is different. According to our previous study [4], 18-69-year-olds' median portion sizes of porridge were $650 \mathrm{~g}$ for males and $480 \mathrm{~g}$ for females. If nutrient contents of porridge are shown per $100 \mathrm{~g}$, it is easy to estimate males' and females' nutrient intakes by multiplying them by 6.5 and 4.8 , respectively.

Both porridges in Table 3 were made by dissolving mixed flour (maize and sorghum flours) in hot water. Since both flours do not contain vitamin A (Table 4), both porridges supplied no vitamin A (Table 3). Table 4 shows that sorghum flour contains 1.6- and 1.8times higher amounts of protein and iron, respectively, compared with maize flour. However, people usually do not cook porridge only with sorghum flour because of its lower yield and higher price relative to maize flour [28]. By adding maize flour, they increase the volume. Household I's porridge had a flour concentration of $8.5 \%$ and that of household II was $6.2 \%$ (Table 3 ). The higher concentration of flours in the porridge of household I than that of household II, meant that it contained more energy, protein, and iron than that of household II. Porridge with more than $13 \%$ of mixed flour concentration could exceed the median energy, protein, and iron contents in $100 \mathrm{~g}$ of porridge observed in the previous study conducted in the eastern part of Rwanda [4]. Therefore, this level of flour concentration is assumed to be acceptable by rural residents. 


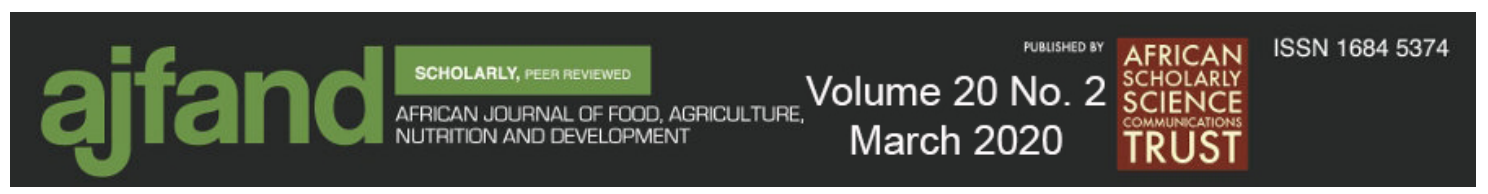

Household II added sugar to porridge. Although sugar could easily increase energy intake, the only nutrient that sugar provides is carbohydrate (Table 4). Even in this small sample, four females out of 30 participants were over-nourished (Table 1). In order to deal with the double burden of malnutrition, addition of sugar is not recommended since it is a source of calories only, without supplying protein and micronutrients [29].

\section{Mixture}

Mixture is a dish made from boiling some foods together. In many other rural areas in Rwanda, the mixture of different food items in a single pot is a common traditional dish $[4,26]$. Table 2 shows that for lunch and dinner, all households cooked mixture one or more times in a day, regardless of their SES. As observed in household IV, when mixture did not contain any roots and tubers, another dish of staple food (in this case, ubugali made of maize flour and boiled water) was consumed with it. The other four out of six mixtures were served as the only dish for one meal.

Table 4 shows energy and nutrient contents of ten ingredients used for six mixtures, and Table 5 shows the quantity of ingredients for cooking $100 \mathrm{~g}$ of mixtures and energy content in $100 \mathrm{~g}$ of the mixtures observed in each household. All of them included beans and salt. Beans and Irish potato were the most popular ingredients for mixture preparation. Except for dinner in household IV, five mixtures contained Irish potato.

Beans, potatoes, and yellow plantain greatly contributed to energy content (Figure 1). One fourth of the six mixtures' energy content on average was derived from beans. As for mixtures containing roots and tubers, this food group contributed on average $73 \%$ of energy content. Table 4 shows that Irish potato has the lowest energy content in the observed three foods in the roots and tubers group. The mixture for lunch in household III included only Irish potato from the roots and tubers group, and energy content in 100 $\mathrm{g}$ of its mixture was $82.0 \mathrm{kcal}$. It was the lowest energy content in the six mixtures. Oil did not greatly contribute to energy content because in most mixtures, its concentration was zero or negligible. 

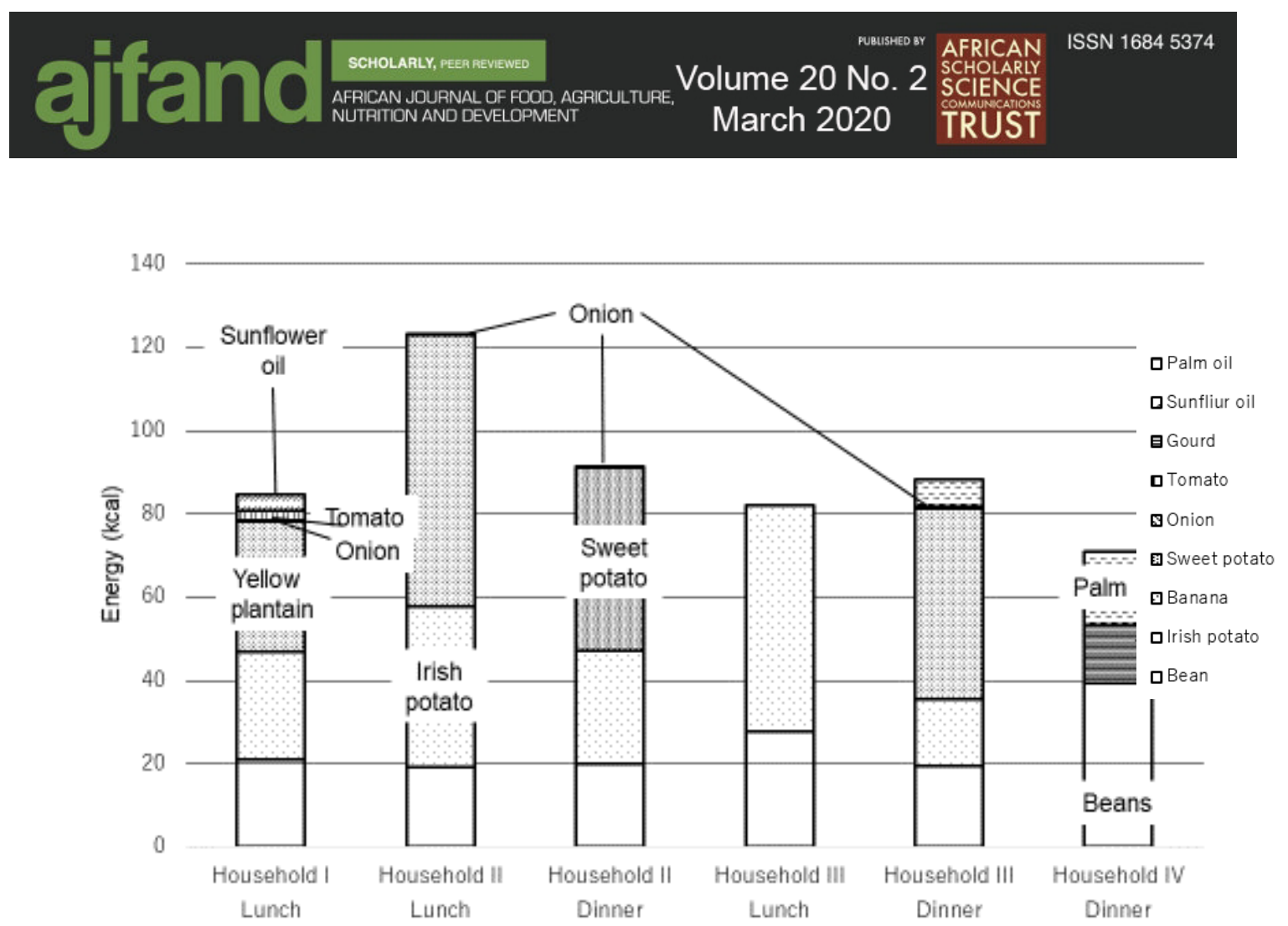

Figure 1: Contributions of each ingredient to energy content in $100 \mathrm{~g}$ of mixture

Beans were significant sources of protein and iron, respectively (Figures 2 and 3). In the four mixtures, over $50 \%$ of the total protein came from beans. Larochelle and Alwang reported that the main protein source in Rwanda is beans [30]. In the remaining two mixtures (lunch and dinner in household II), more than $50 \%$ of the protein was derived from roots and tubers, although Table 4 shows that protein contents in these foods are less than a quarter of that of beans.

According to our previous study [4], 18-69-year-olds' median portion sizes of mixture were $799 \mathrm{~g}$ for males and $689 \mathrm{~g}$ for females. When protein content of $100 \mathrm{~g}$ of mixture is $2.5 \mathrm{~g}$, it is estimated that $20 \mathrm{~g}$ of protein is contained in the median portion size of adult $\operatorname{men}(2.5 * 7.99=20)$. 

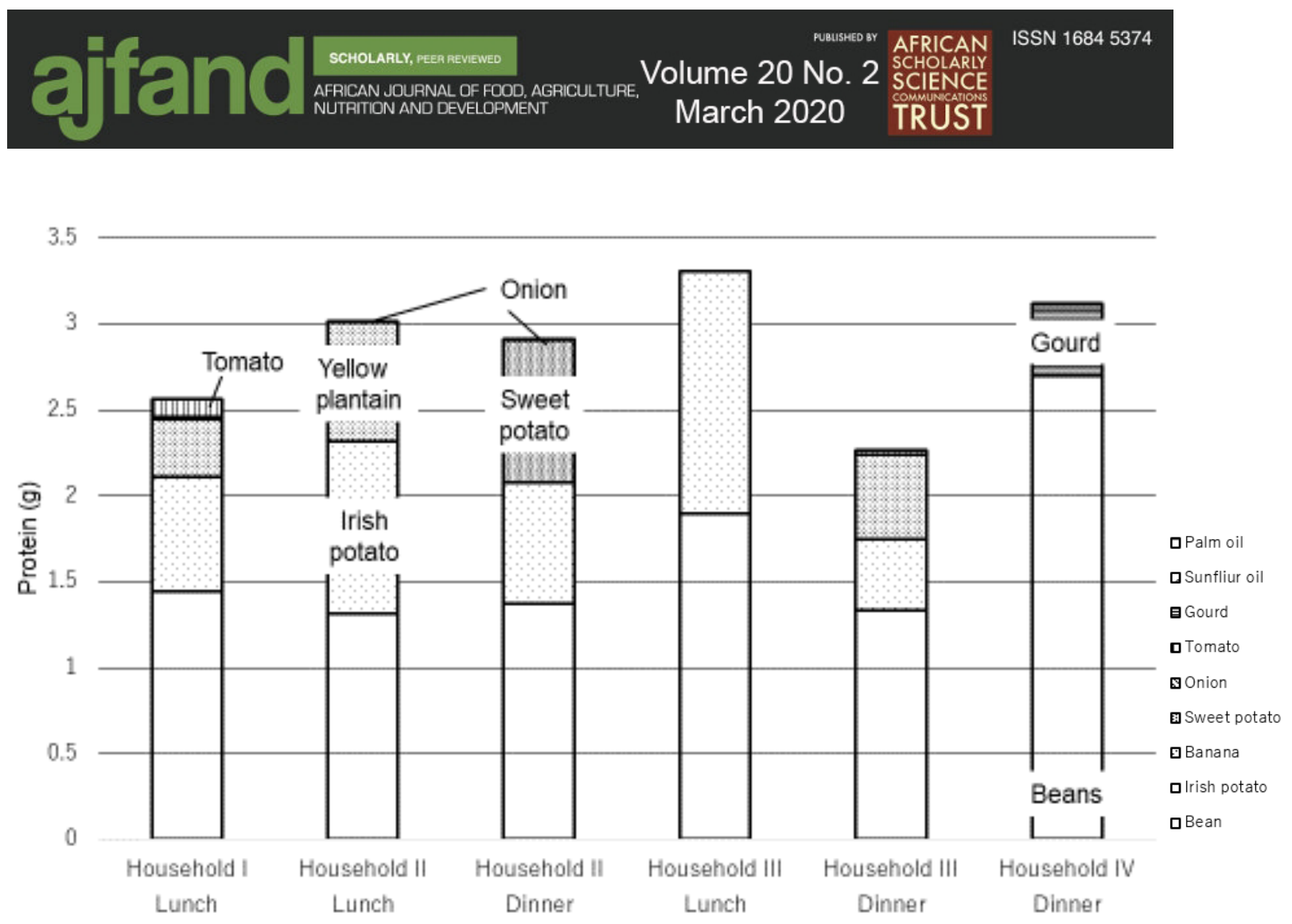

Figure 2: Contributions of each ingredient to protein content in $100 \mathrm{~g}$ of mixture

Figure 3 shows that about $40 \%$ of iron content was derived from beans. Beans are also vital sources of iron [30]. About half of the iron in the mixtures was consumed from roots and tubers, while Table 4 shows that iron contents in these foods are lower than that of beans. According to our previous study [4], 18-69-year-olds' median portion sizes of mixture were $799 \mathrm{~g}$ for males and $689 \mathrm{~g}$ for females. When iron content of $100 \mathrm{~g}$ of mixture is $1 \mathrm{mg}$, it is estimated that $8 \mathrm{mg}$ of iron is contained in the median portion size of adult men $(1 * 7.99=8)$. Contrary to general assumption, yellow plantain and potatoes were the major sources of protein and iron intakes among the participants. Although nonheme iron in roots and tubers has low bio-availability [24], a similar tuber-based dietary pattern was observed in other areas in Rwanda [26]. 

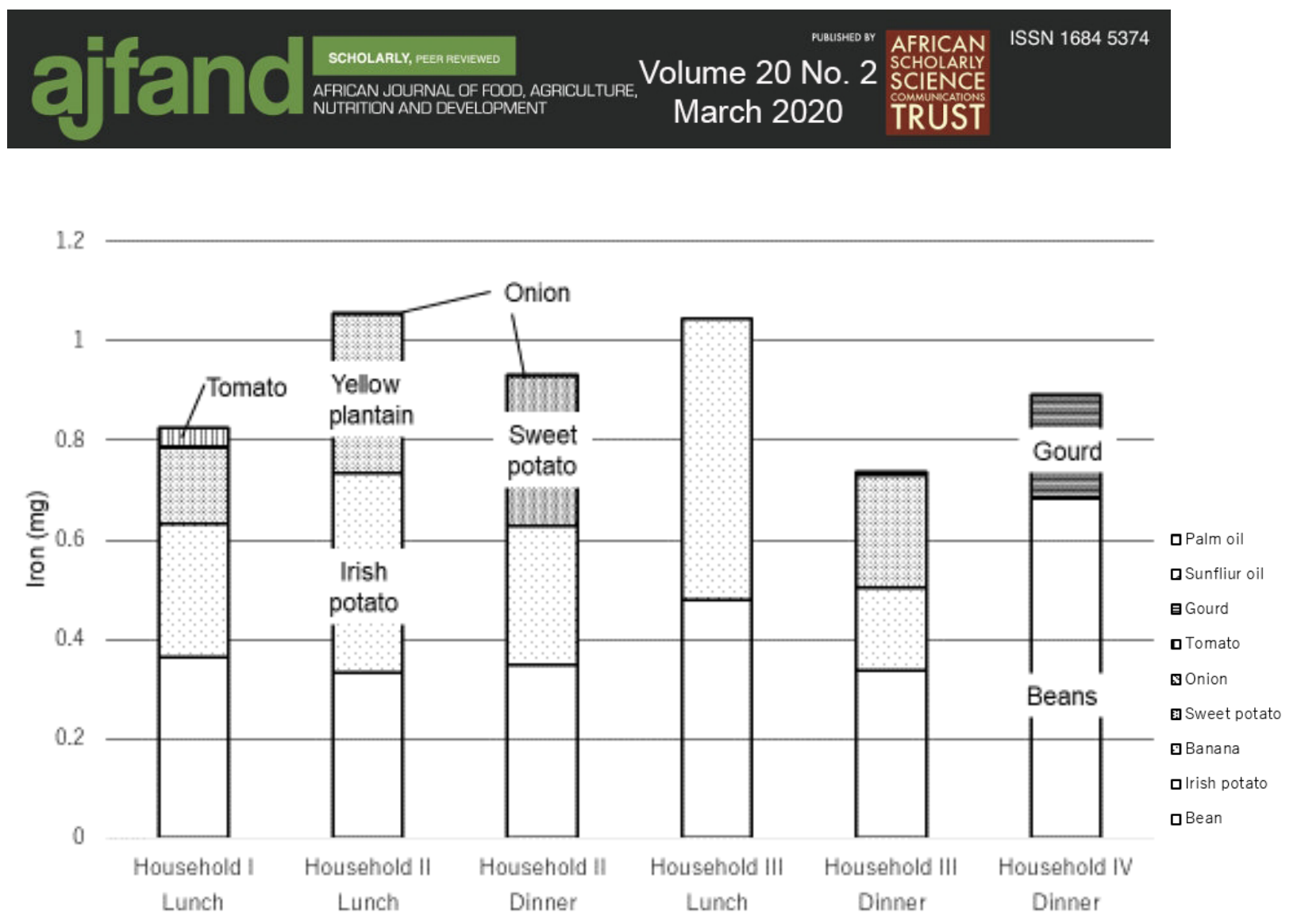

Figure 3: Contributions of each ingredient to iron content in $100 \mathrm{~g}$ of mixture

The total number of ingredients used for cooking the six mixtures was ten (Table 4). Among them, only four ingredients (yellow plantain, palm oil, tomato, and gourd) contain vitamin A. In the roots and tubers food group, vitamin A is contained only in yellow plantain. Yellow plantain contributed to most of the vitamin A content in three mixtures (lunch in household I, lunch in household II, and dinner in household III) where it was used (Table 5). The average amount of yellow plantains for cooking $100 \mathrm{~g}$ of three mixtures were $39 \mathrm{~g}$, and $80 \%$ of vitamin A content was derived from yellow plantain. As for oil, families in this study used two types, palm oil and sunflower oil. Energy contents in the two oils are the same, but vitamin A contents are different (Table 4). Palm oil is rich in vitamin A, while sunflower oil contains no vitamin A. Ninety-five percent of vitamin A content in mixture of household IV was derived from palm oil. Since palm oil was used in households III and IV with lower SES (Table 2), it might be afforded by everyone. Although vegetables did not greatly contribute to vitamin A content $(26 \%$ in household I, and less than five percent in households II, III, and IV), tomato was the most vitamin A-rich food in the three vegetables (tomato, onion, and gourd) observed in this study (Table 4). For cooking mixture, household II used yellow plantain for lunch, but did not use it for dinner. Household III did not use yellow plantain for lunch but used it for dinner. It seems that they chose ingredients for mixture at random without any special 


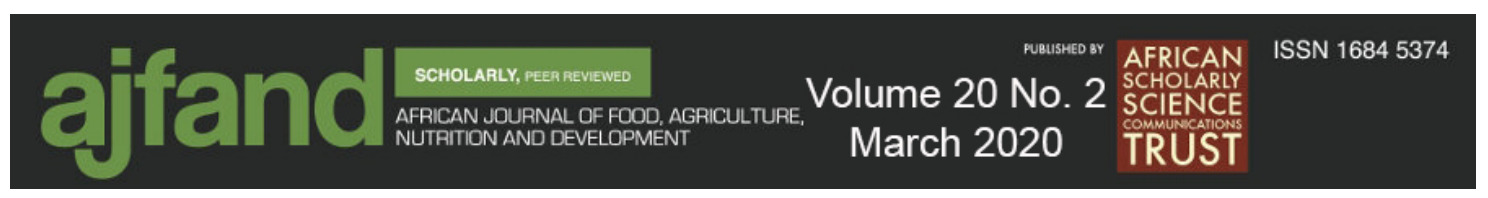

reason. There is a possibility that if they learnt the nutritional value of each food, they could choose wisely, and make their mixture more nutritious.

Energy and nutrient contents in mixtures also depended on concentrations of ingredients. The most energy-dense mixture was observed in the lunch of household II. Its energy content in $100 \mathrm{~g}$ was $123.1 \mathrm{kcal}$, which was more than $30 \mathrm{kcal}$ higher than the median energy content among the six mixtures (Table 5). The cooking process used to prepare this mixture led to the highest amount of evaporation of water of all the mixtures. As a result, the total amount of ingredients used for cooking $100 \mathrm{~g}$ of this mixture was over $100 \mathrm{~g}$. Therefore, the concentrations of ingredients in this mixture became high and the mixture was the most energy-dense. Conversely, the mixture constituting dinner of household III, was not boiled as long and as a result had lower energy content ( $88.3 \mathrm{kcal})$ per $100 \mathrm{~g}$.

\section{Limitations}

Due to the small number of households selected by the subjective judgement of local investigators, this sample may not represent the local population. Although our one-day WFR could not evaluate habitual dietary intake, direct measured body weight and height could reflect their long-term energy balance. Since the one-day WFR was conducted in the dry season, within-individual and seasonal variations could not be assessed. However, our directly observed WFR by experienced specialists could provide precise data including cooking methods and intra-household food allocation without recall and reporting biases. The detailed quantitative and qualitative information of food intake helped us to suggest some realistic approaches for modification of current diets.

\section{CONCLUSION}

Household socioeconomic status did not solely explain the nutritional status of the household members, and the double burden of malnutrition was observed within the richest household. Although meal frequency per day and the number of dishes and ingredients were different by household SES, their diets were characterized by porridge for breakfast and mixture for lunch and dinner. Therefore, these two dishes greatly affected their energy and nutrient intakes. Although porridge did not contain any vitamin A, energy, protein, and iron contents were affected by the concentration of flours. Thick porridge whose flour concentration is $13 \%$ is recommended. The addition of sorghum flour to maize flour could improve the nutritional value of porridge. Beans and potatoes 


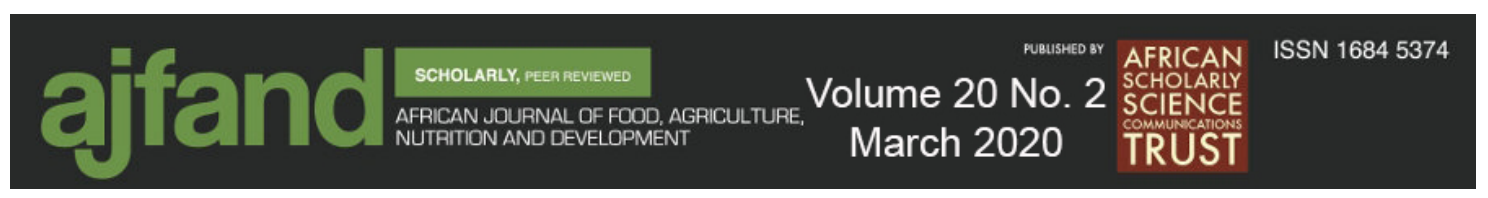

were popular ingredients for mixture and they were major sources of energy, protein, and iron intakes. To cook mixture that contains beans ( $18 \mathrm{~g}$ per $100 \mathrm{~g})$ and potatoes $(35 \mathrm{~g}$ per $100 \mathrm{~g}$ ) and to boil it well might be a feasible way to increase energy and nutrient intakes regardless of household SES. These ingredients and procedures help to cook more nutritional mixtures (over $100 \mathrm{kcal}, 2.8 \mathrm{~g}$ of protein, and $0.9 \mathrm{mg}$ of iron per $100 \mathrm{~g}$ ). In order to ensure supply of the recommended $43 \mu \mathrm{gRE}$ of vitamin A by $100 \mathrm{~g}$ of mixture, addition of the observed three vitamin A-rich foods: yellow plantain (35 g), palm oil (1.5 $\mathrm{g}$ ), and tomato $(10 \mathrm{~g})$, is recommended. Although they were not observed in this study, dark green leaves and milk are available in rural Rwanda and one and a half teacups of chopped dark green leaves and 1 liter of milk contain approximately $500 \mu \mathrm{gRE}$ of vitamin A.

\section{ACKNOWLEDGEMENTS}

The authors appreciate the households who agreed to participate in this study. The authors also appreciate the financial support from Japan International Research Center for Agricultural Sciences for the team to conduct the survey. Special thanks go to the local staff who supported the logistics for the interview and the nutrition survey. The authors also appreciate the financial and technical support of Rwanda Agriculture and Animal Resources Development Board and World Agroforestry. 


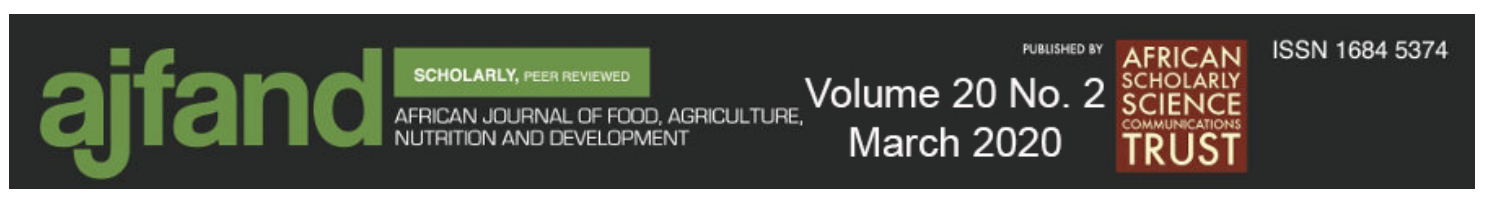

Table 1: Composition of households

\begin{tabular}{|c|c|c|c|c|c|c|}
\hline $\begin{array}{l}\text { Household No., } \\
\text { SES, and size }\end{array}$ & Male & Age & $\begin{array}{c}\mathrm{BMI}^{\mathrm{a}} / \\
\mathrm{z}-\mathrm{score}^{\mathrm{b}}\end{array}$ & Female & Age & $\begin{array}{c}\mathrm{BMI}^{\mathrm{a}} / \\
\mathrm{z}-\mathrm{score}^{\mathrm{b}}\end{array}$ \\
\hline \multirow{5}{*}{$\begin{array}{l}\text { Household I } \\
\text { Better-off } \\
\quad(\mathrm{n}=8)\end{array}$} & Father & 48 & 19.4 & Mother & 47 & 33.3 \\
\hline & Son & 19 & -0.2 & Daughter & 16 & 1.4 \\
\hline & & & & Daughter & 14 & -1.3 \\
\hline & & & & Daughter & 12 & 0.0 \\
\hline & Servant & 26 & 22.0 & Foster daughter & 19 & -2.6 \\
\hline \multirow{5}{*}{$\begin{array}{l}\text { Household II } \\
\text { Medium } \\
\quad(n=7)\end{array}$} & Father & 40 & 23.4 & Mother & 37 & 26.5 \\
\hline & Son & 2 & -0.1 & Daughter & 18 & 1.0 \\
\hline & & & & Daughter & 15 & 1.0 \\
\hline & & & & Daughter & 13 & -1.5 \\
\hline & & & & Daughter & 10 & 2.2 \\
\hline \multirow{6}{*}{$\begin{array}{l}\text { Household III } \\
\text { Medium } \\
(\mathrm{n}=9)\end{array}$} & Father & 56 & 24.7 & Mother & 39 & 19.7 \\
\hline & Son & 17 & -0.1 & Daughter & 13 & 0.0 \\
\hline & Son & 15 & -0.3 & Daughter & 9 & -1.0 \\
\hline & Son & 11 & -1.4 & & & \\
\hline & Son & 6 & $1.3^{\mathrm{c}}$ & & & \\
\hline & Son & 4 & -1.6 & & & \\
\hline \multirow{4}{*}{$\begin{array}{l}\text { Household IV } \\
\qquad \begin{array}{l}\text { Poor } \\
(\mathrm{n}=6)^{\mathrm{e}}\end{array}\end{array}$} & Father & 37 & 24.5 & Mother & 38 & 24.3 \\
\hline & Son & 10 & 0.6 & Daughter & 12 & 0.3 \\
\hline & & & & Daughter & 8 & -0.5 \\
\hline & & & & Daughter & 5 & 0.7 \\
\hline
\end{tabular}

${ }^{a}$ For adults aged 20 years and over

${ }^{\mathrm{b}}$ For 5-19 year-olds, BMI-for-age z-score was calculated. For 1-4 children, heightfor-age z-score (HAZ) was calculated

${ }^{c}$ Participants who were assessed as over-nourished according to the following criteria: adults' BMI was over 25.0, and 5-19 year-olds' BMI-for-age z-score was over +1

d Participants who were assessed as undernourished according to the following criterion: 5-19 year-olds' BMI-for-age z-score was below -2

${ }^{\mathrm{e}}$ One infant under one year old was excluded from data collection 


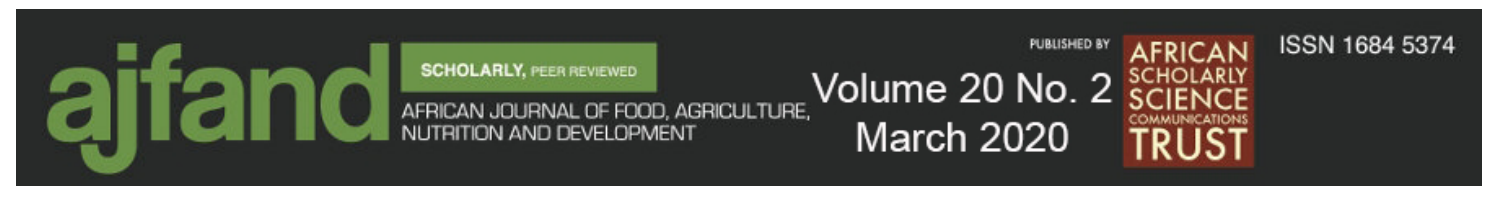

Table 2: Food items consumed during one-day weighed food record

\begin{tabular}{|c|c|c|c|c|c|c|c|c|}
\hline \multicolumn{2}{|l|}{ Household No. } & I & \multicolumn{2}{|c|}{ II } & \multicolumn{2}{|c|}{ III } & \multicolumn{2}{|c|}{ IV } \\
\hline Socioeconomic status & \multicolumn{2}{|c|}{ Better-off } & \multicolumn{2}{|c|}{ Medium } & \multicolumn{2}{|c|}{ Medium } & \multicolumn{2}{|c|}{ Poor } \\
\hline Meal & Name of dish & Ingredients & Name of dish & Ingredients & Name of dish & Ingredients & Name of dish & Ingredients \\
\hline Breakfast & Porridge & $\begin{array}{l}\text { Maize flour, } \\
\text { sorghum flour }\end{array}$ & Porridge & $\begin{array}{l}\text { Maize flour, } \\
\text { sorghum flour, } \\
\text { sugar }\end{array}$ & - & - & - & - \\
\hline Lunch & Mixture & $\begin{array}{l}\text { Irish potato, } \\
\text { yellow plantain, } \\
\text { tomato, bean, } \\
\text { salt, sunflower } \\
\text { oil, onion }\end{array}$ & $\begin{array}{l}\text { Mixture } \\
\text { Avocado }\end{array}$ & $\begin{array}{l}\text { Yellow plantain, } \\
\text { Irish potato, } \\
\text { bean, onion, salt } \\
\\
\text { Avocado }\end{array}$ & Mixture & $\begin{array}{l}\text { Irish potato, } \\
\text { bean, salt }\end{array}$ & - & - \\
\hline Dinner & $\begin{array}{l}\text { Rice } \\
\text { Soup } \\
\text { Beef Stock }\end{array}$ & 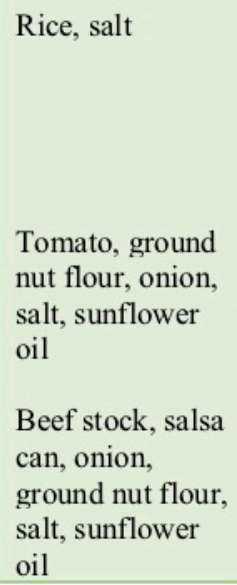 & Mixture & $\begin{array}{l}\text { Sweet potato, } \\
\text { Irish potato, } \\
\text { onion, bean, salt }\end{array}$ & Mixture & $\begin{array}{l}\text { Yellow plantain, } \\
\text { Irish potato, } \\
\text { bean, tomato, } \\
\text { palm oil, onion, } \\
\text { salt }\end{array}$ & $\begin{array}{l}\text { Mixture } \\
\text { Ubugali }\end{array}$ & $\begin{array}{l}\text { Gourd, bean, } \\
\text { palm oil, salt }\end{array}$ \\
\hline
\end{tabular}




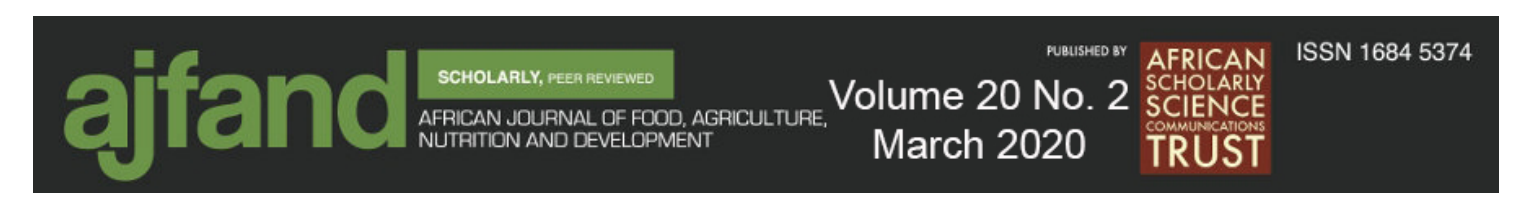

Table 3: Energy and nutrient contents in $100 \mathrm{~g}$ of porridge

\begin{tabular}{|c|c|c|c|c|c|c|c|c|c|c|}
\hline \multirow[b]{2}{*}{ Ingredients } & \multicolumn{5}{|c|}{ Household I } & \multicolumn{5}{|c|}{ Household II } \\
\hline & $\begin{array}{c}\text { Quantity } \\
\text { (g) }\end{array}$ & $\begin{array}{c}\text { Energy } \\
\text { (kcal) }\end{array}$ & $\begin{array}{c}\text { Protein } \\
(\mathrm{g})\end{array}$ & $\begin{array}{c}\mathrm{VA} \\
(\mu \mathrm{gRE})\end{array}$ & $\begin{array}{l}\text { Iron } \\
(\mathrm{mg})\end{array}$ & $\begin{array}{c}\text { Quantity } \\
\text { (g) }\end{array}$ & $\begin{array}{c}\text { Energy } \\
\text { (kcal) }\end{array}$ & $\begin{array}{c}\text { Protein } \\
(\mathrm{g})\end{array}$ & $\begin{array}{c}\mathrm{VA} \\
(\mu \mathrm{gRE})\end{array}$ & $\begin{array}{l}\text { Iron } \\
\text { (mg) }\end{array}$ \\
\hline Maize flour & 4.25 & 15.3 & 0.29 & 0 & 0.10 & 3.54 & 12.8 & 0.24 & 0 & 0.08 \\
\hline Sorghum flour & 4.25 & 14.4 & 0.48 & 0 & 0.18 & 2.65 & 9.0 & 0.30 & 0 & 0.11 \\
\hline Water & 91.50 & 0 & 0 & 0 & 0 & 92.51 & 0 & 0 & 0 & 0 \\
\hline Sugar & 0 & 0 & 0 & 0 & 0 & 1.32 & 5.11 & 0 & 0 & 0 \\
\hline Total & 100 & 29.8 & 0.77 & 0 & 0.28 & 100 & 21.7 & 0.54 & 0 & 0.19 \\
\hline
\end{tabular}




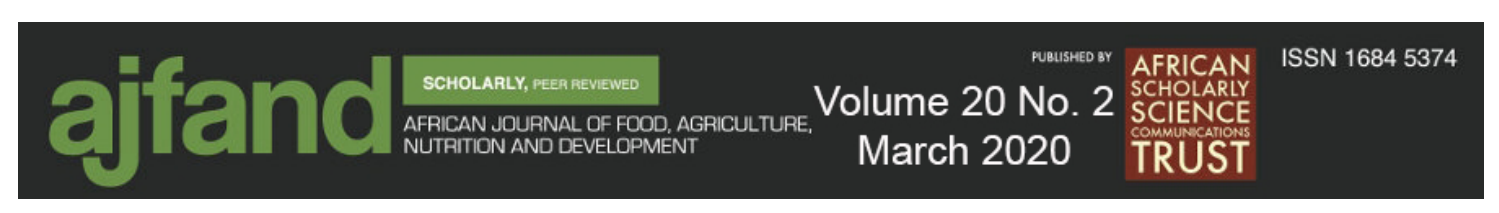

Table 4: Energy and nutrient contents in $100 \mathrm{~g}$ of food items used for cooking of two porridges and six mixtures

\begin{tabular}{|c|c|c|c|c|c|c|}
\hline & Food groups & Food items & $\begin{array}{c}\text { Energy } \\
(\mathrm{kcal})\end{array}$ & $\begin{array}{l}\text { Protein } \\
(\mathrm{g})\end{array}$ & $\begin{array}{c}\text { Vitamin A } \\
(\mu \mathrm{gRE})\end{array}$ & $\begin{array}{l}\text { Iron } \\
(\mathrm{mg})\end{array}$ \\
\hline \multirow{3}{*}{$\begin{array}{c}\text { Ingredients of } \\
\text { porridge }\end{array}$} & Grains and grain products & Maize flour & 361 & 6.9 & 0 & 2.4 \\
\hline & & Sorghum flour & 339 & 11.3 & 0 & 4.2 \\
\hline & Sugar and sweets & Sugar & 387 & 0 & 0 & 0 \\
\hline \multirow{10}{*}{$\begin{array}{l}\text { Ingredients of } \\
\text { mixture }\end{array}$} & Roots and tubers & Irish potato & 77 & 2.0 & 0 & 0.8 \\
\hline & & Sweet potato & 117 & 2.2 & 0 & 0.8 \\
\hline & & Yellow plantain & 122 & 1.3 & 56 & 0.6 \\
\hline & Beans, nuts, and seeds & Beans & 127 & 8.7 & 0 & 2.2 \\
\hline & Fats and oils & Sunflower oil & 884 & 0 & 0 & 0 \\
\hline & & Palm oil & 884 & 0 & 1269 & 0 \\
\hline & Vegetables & Onion & 40 & 1.1 & 0 & 0.2 \\
\hline & & Tomato & 18 & 0.9 & 42 & 0.3 \\
\hline & & Gourd $^{\mathrm{a}}$ & 20 & 0.6 & 2 & 0.3 \\
\hline & Miscellaneous & Salt & 0 & 0 & 0 & 0 \\
\hline
\end{tabular}

Source: A Food Composition Tables for Central and Eastern Uganda [17]

${ }^{\text {a }}$ Because there was no data for gourd in the food composition tables of Uganda, the values of "green-colored chayote" in the Standard Tables of Food Composition in Japan were used for gourd [18] RE: retinol equivalent 


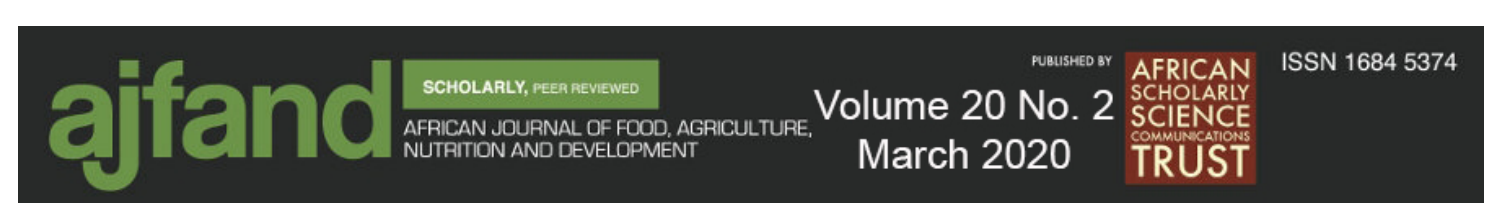

Table 5: Weights of each ingredient for cooking $100 \mathrm{~g}$ of mixture and energy content in $100 \mathrm{~g}$ of mixture

\begin{tabular}{|c|c|c|c|c|c|c|c|c|c|}
\hline & \multirow{2}{*}{$\begin{array}{c}\text { Household No. } \\
\text { Meal }\end{array}$} & \multirow{2}{*}{$\begin{array}{c}\text { I } \\
\text { Lunch }\end{array}$} & \multicolumn{2}{|c|}{ II } & \multicolumn{2}{|c|}{ III } & \multirow{2}{*}{$\begin{array}{c}\text { IV } \\
\text { Dinner }\end{array}$} & \multirow{2}{*}{ Median } & \multirow{2}{*}{ (25\% tile- $75 \%$ tile) } \\
\hline & & & Lunch & Dinner & Lunch & Dinner & & & \\
\hline \multicolumn{10}{|l|}{ Weights of each ingredient } \\
\hline Food groups & Food items & $(\mathrm{g})$ & $(\mathrm{g})$ & $(\mathrm{g})$ & (g) & $(\mathrm{g})$ & $(\mathrm{g})$ & & $(\mathrm{g})$ \\
\hline \multirow{3}{*}{ Roots and tubers } & Irish potato & 33.5 & 50.2 & 35 & 70.6 & 20.7 & 0 & \multirow{3}{*}{64.9} & \multirow{3}{*}{$(58.6-72.1)$} \\
\hline & Sweet potato & 0 & 0 & 37.6 & 0 & 0 & 0 & & \\
\hline & $\begin{array}{l}\text { Yellow } \\
\text { plantain }\end{array}$ & 25.6 & 53.4 & 0 & 0 & 37.7 & 0 & & \\
\hline Beans, nuts, and seeds & Beans & 16.6 & 15.1 & 15.8 & 21.8 & 15.3 & 31.0 & 16.2 & $(15.4-20.5)$ \\
\hline \multirow{2}{*}{ Fats and oils } & Sunflower oil & 0.5 & 0 & 0 & 0 & 0 & 0 & \multirow{2}{*}{0.3} & \multirow{2}{*}{$(0.0-0.7)$} \\
\hline & Palm oil & 0 & 0 & 0 & 0 & 0.7 & 2 & & \\
\hline \multirow{3}{*}{ Vegetables } & Onion & 1.0 & 0.5 & 0.9 & 0 & 0.1 & 0 & \multirow{3}{*}{1.9} & \multirow{3}{*}{$(0.6-10.6)$} \\
\hline & Tomato & 12.2 & 0 & 0 & 0 & 2.8 & 0 & & \\
\hline & Gourd & 0 & 0 & 0 & 0 & 0 & 69.4 & & \\
\hline Miscellaneous & Salt & 0.6 & 0.5 & 0.5 & 0.6 & 0.5 & 0.7 & 0.6 & $(0.5-0.6)$ \\
\hline Total & & 89.8 & 119.6 & 89.9 & 93.0 & 77.7 & 103.2 & 91.4 & $(89.8-100.7)$ \\
\hline \multirow[t]{2}{*}{ Energy content } & & (kcal) & (kcal) & (kcal) & (kcal) & (kcal) & (kcal) & \multicolumn{2}{|r|}{ (kcal) } \\
\hline & & 84.6 & 123.1 & 91.4 & 82.0 & 88.3 & 115.4 & 89.9 & $(85.5-109.4)$ \\
\hline
\end{tabular}

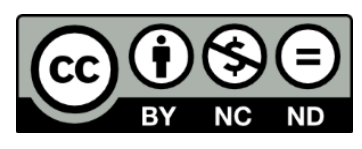




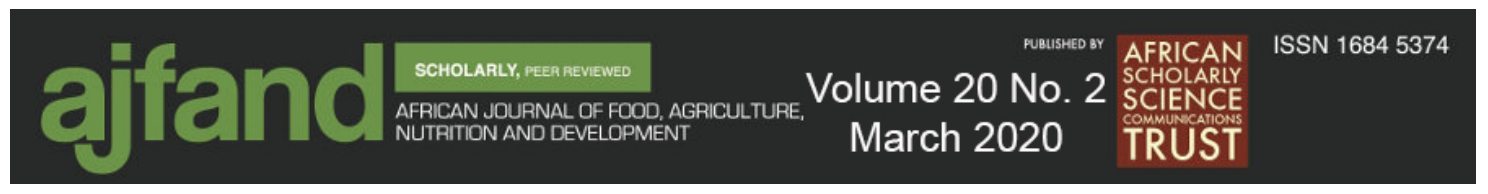

\section{REFERENCES}

1. Republic of Rwanda. National Food and Nutrition Policy. Republic of Rwanda, Kigali. 2014.

2. Uccello E, Kauffmann D, Calo $M$ and $M$ Streissel Nutrition-sensitive Agriculture and Food Systems in Practice. FAO, Rome. 2017.

3. Ecker O, Weinberger $\mathbf{K}$ and $\mathbf{M}$ Qaim Patterns and Determinants of Dietary Micronutrient Deficiencies in Rural Areas of East Africa. African Journal of Agricultural and Resource Economics 2010; 4: 175-194.

4. Yanagisawa A, Sudo N, Amitani Y, Caballero Y, Sekiyama M, Mukamugema C, Matsuoka T, Inanishi H, Sasaki $\mathbf{T}$ and $H$ Matsuda Development and Validation of a Data-based Food Frequency Questionnaire for Adults in Eastern Rural Area of Rwanda. Nutrition and Metabolic Insights 2016; 9: 31-42.

5. Republic of Rwanda. Non-communicable Diseases Risk Factors Report. Ministry of Health, Kigali. 2015.

6. Sanusi RA, Badejo CA and BO Yusuf Measuring Household Food Insecurity in Selected Local Government Areas of Lagos and Ibadan. Pakistan Journal of Nutrition. 2006; 5: 62-67.

7. Sirotin N, Hoover D, Segal-Isaacson CJ, Shi Q, Adedimeji A, Mutimura E, Cohen $M$ and $K$ Anastos Structural Determinants of Food Insufficiency, Low Dietary Diversity and BMI: A Cross-sectional Study of HIV-infected and HIVnegative Rwandan Women. BMJ Open 2012; 2: e000714.

8. Okello JJ, Sindi K, Low J and K Shikuku Hidden Hunger or Knowledge Hunger? Nutritional Knowledge, Diet Diversity and Micronutrient Intake in Rwanda: The Case of Vitamin A. Paper prepared for presentation at the African Association of Agricultural Economists Conference, Tunisia, 22-25 September 2013. 


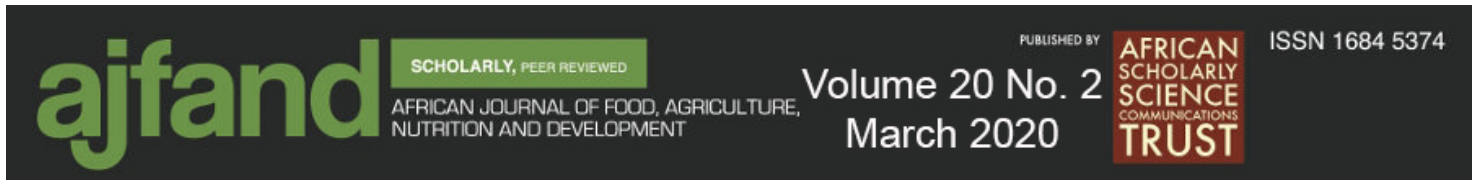

9. Harris-Fry H, Azad K, Kuddus A, Shara S, Nahar B, Hossen M, Younes L, Costello A and E Fottrell Socio-economic Determinants of Household Food Security and Women's Dietary Diversity in Rural Bangladesh: A Cross-sectional Study. Journal of Health, Population and Nutrition 2015; 33: 2.

10. National Institute of Statistics of Rwanda. 2016/2017 Rwanda Poverty Profile Report. National Institute of Statistics of Rwanda, Kigali. 2018.

11. Maniriho A and AR Bizoza Determinants of Crop Production in Musanze District, Northern Rwanda. East Africa Research Paper in Economics and Finance EARPEF. 2018; 36.

12. National Institute of Statistics of Rwanda, Ministry of Finance and Economic Planning and Ministry of Health. Rwanda Demographic and Health Survey 2014-15 Final Report. Republic of Rwanda, Kigali. 2016.

13. Stephen BH, Steven RC, Warren SB, Deboran GG and BN Thomas Designing Clinical Research Fourth Edition. Lippincott Williams \& Wilkins, Philadelphia 2013.

14. National Institutes of Health, National heart, Lung and Blood Institute. Clinical Guidelines on the Identification, Evaluation and Treatment of Overweight and Obesity in Adults, The Evidence Report. National Heart, Lung and Blood Institute, Rockville. 1998.

15. Butte NF, Garza $C$ and MD Onis Evaluation of the International Growth Standards for School-aged Children and Adolescents. The Journal of Nutrition 2007; 137: 153-157.

16. World Health Organization. WHO Child Growth Standards, Length/height-forage, Weight-for-age, Weight-for-length, Weight-for-height and Body Mass Indexfor-age, Methods and Development. World Health Organization, Geneva. 2006.

17. Hotz C A Food Composition Table for Central and Eastern Uganda, HarvestPlus Technical Monograph Series 9. HarvestPlus, Washington DC. 2012. 


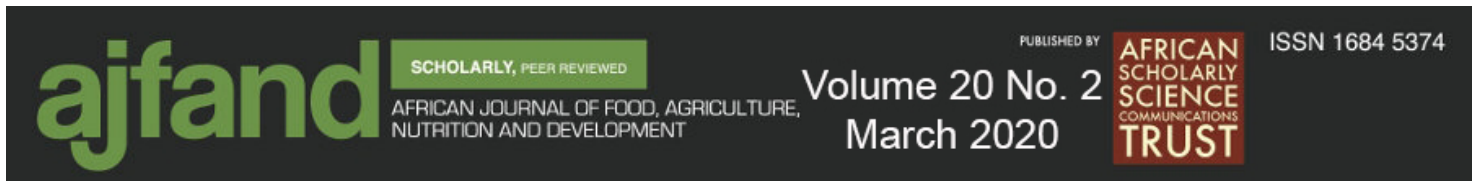

18. Ministry of Education, Culture, Sports, Science and Technology, Japan. Standard Tables of Food Composition in Japan-2015- (seventh revised version), Tokyo. 2015.

19. Haddad L, Hoddinott $\mathbf{J}$ and $\mathbf{H}$ Alderman The Scope of Intrahousehold Resource Allocation Issues. In: Haddad L, Hoddinott $\mathrm{J}$ and $\mathrm{H}$ Alderman (Eds). Intrahousehold Resource Allocation in Developing Countries. Johns Hopkins University Press, Baltimore. 1997: 1-16.

20. World Health Organization. The Double Burden of Malnutrition, Policy Brief. World Health Organization, Geneva. 2017.

21. Zhao W, Yu K, Zheng Y, Zhao A, Wang $\mathbf{P}$ and $Y$ Zhang Dietary Diversity Scores: An Indicator of Micronutrient Inadequacy Instead of Obesity for Chinese Children. BMC Public Health. 2017; 17: 440.

22. Speedy AW Global Production and Consumption of Animal Source Foods. The Journal of Nutrition 2003; 133: 4048S-4053S.

23. Sudo N, Sekiyama M, Watanabe C, Mozammel ATM and R Ohtsuka Gender Differences in Food and Energy Intake Among Adult Villagers in Northwestern Bangladesh: A Food Frequency Questionnaire Survey. International Journal of Food Sciences and Nutrition. 2004; 55: 499-509.

24. Sudo N, Sekiyama M, Maharjan $M$ and $R$ Ohtsuka Gender Differences in Dietary Intake Among Adults of Hindu Communities in Lowland Nepal: Assessment of Portion Sizes and Food Consumption Frequencies. European Journal of Clinical Nutrition 2006; 60: 469-477.

25. Sudo N, Sekiyama M, Ohtsuka $R$ and M Maharjan Gender Differences in "Luxury Food Intake" Owing to Temporal Distribution of Eating Occasions among Adults of Hindu Communities in Lowland Nepal. Asia Pacific of Clinical Nutrition 2009; 18: 441-446.

26. Kano M, Sudo N, Yanagisawa A, Amitani Y, Caballero Y, Sekiyama M, Christine M, Matsuoka T, Imanishi H, Sasaki T and H Matsuda Validity of The Minimum Dietary Diversity for Women of Reproductive Age (MDD-W) in Rural Rwanda. Japanese Journal of Health and Human Ecology 2017; 83: 150162. 


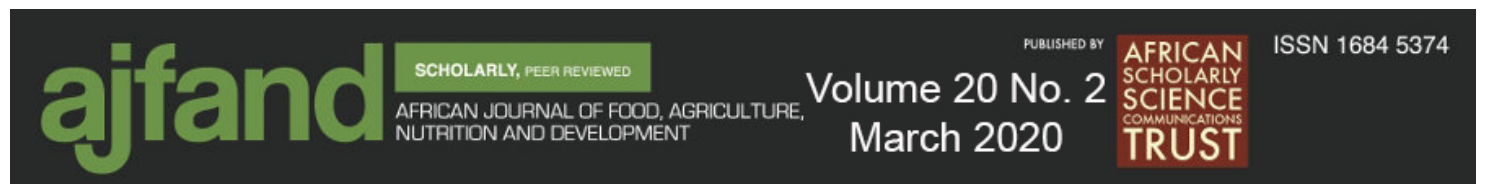

27. Fan S, Yosef S and R Pandya-Lorch Agriculture for Improved Nutrition: Seizing the Momentum. International Food Policy Research Institute, Washington DC. 2019.

28. Tomomatsu Y Gendered Economies of Agriculture, The Transformation of Everyday Livelihoods in Northern Ghana. Akashi Bookstore, Tokyo. 2019.

29. King FS, Burgess A, Quinn VJ and AK Osei Nutrition for Developing Countries, Third Edition. Oxford University Press, New York. 2015.

30. Larochelle $\mathbf{C}$ and $\mathbf{J}$ Alwang Impacts of improved bean varieties on food security in Rwanda. Selected paper for presentation at the Agricultural and Applied Economics Association's 2014 AAEA Annual Meeting, Minneapolis July 27-29 2014. 